\title{
Times of COVID-19 Pandemic and its Impact: Rethinking the Public Sector Practices in Zimbabwe
}

\author{
Zvimekria Clive Mukushwa $^{1 *}$, Enock Chikohora ${ }^{2}$ \\ ${ }^{1}$ Ph.D candidate in Local Governance Studies, Midlands State University, Gweru, Zimbabwe \\ ${ }^{2}$ Lecturer: Department of Peace, Leadership and Conflict Resolution, Zimbabwe Open University, Bulawayo, Zimbabwe \\ *Corresponding author
}

\begin{abstract}
The public sector is widely recognised as one of the strategic providers of goods and services to ameliorate public welfare. Besides this, the public sector also formulates and implements macro-socio-economic policies to create a predictable, consistent and transparent investment climate. However, the advent of COVID-19 pandemic abruptly in late 2019 in China has undoubtedly reconfigured the traditional working landscape of the public sector internationally. Zimbabwe is no exception. One ponders how Zimbabwe weathered to this magnitude global catastrophe to be ahead of the curve and stay operational since its traditional practice were almost made redundant. There is still paucity of literature on COVID-19 pandemic and public sector governance. Hence, this paper assessed the impact of COVID-19 pandemic and government regulations to the public sector practices in Zimbabwe. It also evaluated the efficacy of COVID-19 preventative measures in suppressing the virus. This paper was largely qualitative study hinged on document analytic approach and snap survey. This paper argued that for public sector institutions to cope with the 'new normal', they should strategically rethink its philosophy of public sector practices. Analysis of recent literature that show that this global threat has unprecedentedly forced the government to trim its workforce to work physically and deferment of development projects as well as caused deaths of critical expertise and loss of revenue, among others. Debatably, the advent of COVID-19 pandemic is a wakeup call for Zimbabwe to learn some critical lessons and insights to capitalise on new opportunities presented to modernise its practice. Even though innovative digital strategies were adopted minimally, this paper further recommends that the public sector institutions should strengthen the espousal of contemporary digital systems sustainably to stay afloat in hard times of this crisis and post-COVID-19 bane.
\end{abstract}

Keywords: COVID-19 Pandemic, Public Sector Practices, Government regulations, Zimbabwe.

\section{INTRODUCTION}

$\mathrm{P}$ ublic sector entails governments and all publicly controlled or publicly funded agencies, enterprises, and other entities that deliver public programs, goods or services (The Institute of Internal Auditors, 2011). In our context, they include ministries, parastatals, departments and agencies. In Zimbabwe, the public sector has a chequered history with footprints that dates back to pre-colonial era, which means the public has travelled through various phases of reformations to improve its effectiveness and response to prevailing international best practices. During the colonial era, the public sector was largely designed to benefit the white minority at the expense of African indigenous community (Chimbowu, 2010). The attainment of political independence in 1980 witnessed the introduction of legal, institutional and policy frameworks to reform the nature of the inherited public sector systems which was characterised by segregation. As observed by Betchoo, $2016 \&$ Therkildsen (2001), the earlier public sector reforms were aimed to spearhead socio-economic development to benefit the previously peripherised black indigenous citizens. These reforms did not happen to Zimbabwe only, but in other African countries that were trying to recover from decades of colonisation. The public sector reformations were also inspired by the New Public Management model (Larbi, 1998 \& Hood, 1991). New Public Management was designed to cut public sector costs, ensure private sector-style of management practices are applied to increase flexibility in decision-making, competition in the public sector (through term contracts and tendering) must be increased, decentralisation of powers and responsibilities to increase competition amongst them and explicit standards and performance measures must be established. The Public Sector Reform (PSR) implemented globally was also a vehicle to improve performance, mostly through improving state capability to sustainably generate and distribute public goods (Gwata-Charamba, 2020). More so, the adoption of Economic Structural Adjustment Programmes (ESAPs) around 1990s to liberalise the economic structures among other issues also immensely contributed to public sector reforms (Brotchwey, Collier, Gunning \& Hamada, 1998). Thus, the sector of public institution prior to the advent of COVID-19 pandemic (coronavirus disease) should be understood within this historical context in Zimbabwe.

Furthermore, at the time of writing, most global countries including Zimbabwe were facing unprecedented COVID-19 pandemic which was first detected in Wuhan city, Hubei province in China around late December in 2019 (World Health Organisation (WHO), 2020). Interestingly, as of 17 September 2021, there were some countries that had not recorded a COVID-19 case. (Stephens, 2021). The countries are: North Korea, Turkmemstan, Tuvalu and Nauru in Pacific Island in Oceania. World Health Organisation officially declared Coronavirus disease a 'pandemic' on $11^{\text {th }}$ March 2020 due to its speed and scale of transmission and fatalities on humans (World Health Organisation (WHO), 2020). 
Pandemic refers to the widespread emergence of a disease over one region of the world (Morens, Taubenberger \& Fauci, (2009). The virus can be transmitted from human-to-human through respiratory droplets, close contact with infected patients and possibly by fecal-oral and aerosol contact (Hindson, 2020 \& Xu et al., 2020). There are some number symptoms that characterise the pandemic. Most common symptoms of COVID-19 include fever, cough, myalgia while minor ones range from sore throat, headache, chills, nausea or vomiting, dirrahoea, ageusia and conjunctival congestion (Umankanthan, Sahu, Ranade, Maryan, Bukelo, Rao, Abrahao-Machando, Dahal, Kumar \& Dhananyayar, 2020). To date, the pandemic has briskly spread to the rest of the world causing gargantuan havoc to the economy, human life, democracy and public sector performance. Global epidemiological data on COVID-19 pandemic is still mixed. Globally, as of 22 September 2021, there were 229, 373, 963 confirmed COVID-19 cases, including 4, 705, 111 deaths (WHO, 2021). While, as at 21 September 2021, Zimbabwe had 128464 confirmed cases, including 121440 recoveries and 4576 deaths while those vaccinated against virus were 2976512 (Ministry of Health and Child Care (MoHCC), 2021).

Depth analysis of available literature on public sector has shown that most publication were done pre-COVID-19 era (e.g., Alinska, Filipiak \& Kosztowniak, 2018; Popa, 2017; Betchoo, 2016; Curristine, Lonti \& Joumard, 2007; Jan-Erik, 2000). These scholars interrogated its challenges, opportunities, concepts, importance and approaches. At the time of writing, few studies had specifically assessed COVID19 impact on public sector. They looked on the role of the public sector in the aftermath of COVID-19 pandemic crisis (Palrao, Rodrigues \& Estevao, 2021); impact of COVID-19 pandemic in Zimbabwe's public sector (health sector) (Chilunjika, Chilinjika \& Mutizwa, 2020; the impact of COVID-19 public sector insurance (Government Actuary's Department (GAD), 2020) and COVID-19 and public sector capacity (Mazzuacato \& Kattel, 2020). This thus opens a unique gap that might be narrowed by this article after building on aforementioned extant studies. It was against this background that this paper cross-sectionally assessed the impact of COVID-19 pandemic and government regulations to the public sector practices in Zimbabwe. This article contributes to extant literature in number of ways. First, this paper narrows the gaps identified in COVID-19 lockdown rules-public sector nexus. Second, it adds valuable literature to issues of COVID-19 lockdown rules and public sector institutions. Third, it provides findings and conclusions that can stimulate further studies building this research. On the other hand, the findings and conclusions will help public sector institutions to critically introspect its governance modalities in the context of COVID-19 pandemic and associated regulations.

\section{RESEARCH METHODOLOGY}

This article largely reviewed qualitative literature through a document analytic and snap survey. Document analysis is a systematic procedure for reviewing or evaluating documentsboth printed and electronic material (Bowen, 2009). This data was examined and interpreted in order to elicit meanings, gain understanding and develop empirical knowledge (Corbin \& Strauss, 2008). The rationale for settling for document analysis was to track the changes and developments in the public sector as a result of COVID-19 pandemic in Zimbabwe. This technique was selected because of availability of data, its cost-effectiveness and convenience as compared to other techniques. Literature was sourced from the Constitution of Zimbabwe, books, journal articles, newspapers, and COVID-19 laws and policies. In addition to this, a snap survey was conducted to gain an in-depth and contextual understanding of the COVID-19 situation on public sector in selected institutions of Harare and Bulawayo.

\section{RESULTS AND DISCUSSION OF FINDINGS}

\section{Government's Response Mechanisms and their Efficacy}

The following Figure 1 displays a mélange of COVID-19 response mechanisms implemented by the Government of Zimbabwe in order to curtail the continual spread of the lethal virus.

Figure 1: Government's Response Mechanisms to COVID-19 Pandemic

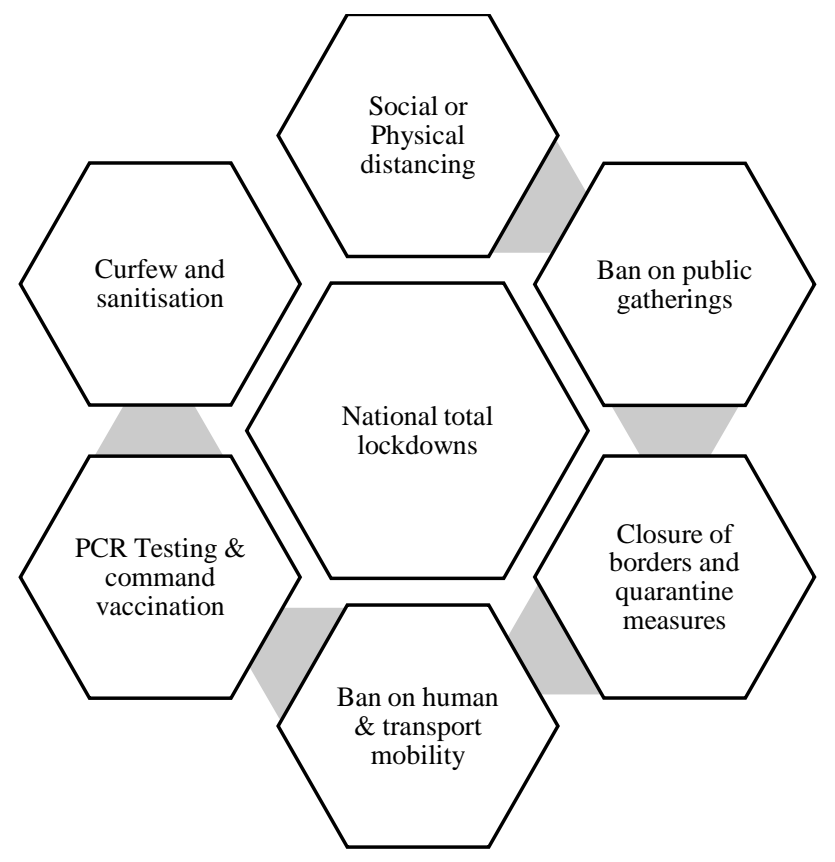

Authors' design.

As presented in above figure, a number of punitive counter measures were formulated to fight COVID-19 pandemic since its inception in 2019. The global health body (World Health Organisation) led governments and other societies in introducing these measures. Commendably, the Government of Zimbabwe (GoZ) also responded positively by deploying WHO guidelines to complement those designed locally. In 
this section, the efficacy of these preventative measures is evaluated through multidimensional issues that includes global ranking indexes, COVID-19 infection and recoveries, number tests, vaccination and death cases. This helped to make definitive evidence on whether these measures worked (or are working) in suppressing the spread of the virus in the country. On the $27^{\text {th }}$ May 2020, President Mnangagwa's administration declared a state of national emergency in response to COVID-19 pandemic in terms of the Civil Protection Act of 1989 (Mukushwa, Mapuva \& Mutema, 2021; Moyo \& Phulu, 2021). From 30 March to 19 April 2020 , the country was put under 21-day total lockdown to combat coronavirus transmission (Mtingondo, 2020). A Statutory Instrument number 98 of 2020 on Public Health (COVID-19 Prevention, Containment and Treatment) regulations was effected. It enveloped response measures that include ban on human movements, schools, entertainment and recreational activities, public gathering was strictly limited to 50 people and restriction of hospital visits. Other safety measures are social distancing, wearing of face masks, sanitisation of hands and stay-at-home orders.

At one time, those working in essential services were mandated to present exemption letters to gain passage at roadblocks or during joint police-military patrols. Security apparatus such as the police (Zimbabwe Republic Police) and soldiers (Zimbabwe Military Police) were deployed to enforce these regulations through mounting roadblocks and conduct joint police-military patrols countrywide. Moyo \& Phulu (2021) criticised the idea of adopting a highly securitised approach to enforce COVID-19 regulations as it could be intended to achieve some objectives beyond public health concerns. Nevertheless, these COVID-19 strategies are being revised by the government based on prevailing virus situation in the country. At the time of writing, the government had relaxed these regulations to allow the public sector institutions to operate fully. The government also adopted a 'Command Vaccination Approach' (CVA) following procurement of COVID-19 vaccines from China, India and Russia to complement those donated by these countries in order to reach head immunity. Following low vaccination uptake, the government thus set a deadline date for public workers to be fully vaccinated in order to access government buildings and continue to receive COVID-19 allowance. One ponders whether these COVID-19 preventative measures have so far worked (or are working) and if so, to what extent.

Using the trend analysis provided by COVID-19 Performance Index and Nikkei COVID-19 Recovery Index, it seems Zimbabwe has performed averagely on combating the virus as at March 2021. For example, a COVID-19 Performance Index (Australian think tank) of $9^{\text {th }}$ January 2021 ranked Zimbabwe number 38 of 98 countries with performance percentage of 54.6 (Lowy Institute (LI), 2021). In these results, the top ten was occupied by countries such as New Zealand (94.4 percent), Vietnam (90.8 percent), Taiwan (86.4 percent), Thailand ( 84.2 percent), Cyprus ( 83.3 percent), Rwanda ( 80.8 percent), Iceland (80.1 percent), Australia (77.9 percent),
Latvia (77.5 percent) and Sri Lanka (76.8 percent) while the bottom was occupied by USA (17.3 percent), Iran (15.9 percent), Colombia (7.7 percent), Mexico (6.5 percent) and Brazil (4.3 percent). As of 12 July 2021, the COVID-19 Performance Index further ranked Zimbabwe to position 42 of 116 countries analysed with 51.8 percent (Lowy Institute (LI), 2021). By looking at these results, Zimbabwe dropped by 2.8 percent and fall by 4 places which means that it performed negatively during this period. On the other hand, Nikkei COVID-19 Recovery Index of $7^{\text {th }}$ July 2021 ranked Zimbabwe number 52 out of 121 countries with percentage of $54.0(\mathrm{Li}, 2021)$. Analysis of these results are general showing that the country performed well as compared to USA, Iran, Colombia, Mexico and Brazil. One can conclude that the average ranking of Zimbabwe may mean that COVID-19 infection and death cases were slightly declining while recoveries increased. To support this conclusion, during a Post-Cabinet Media Meeting on 27 July 2021, Information Minister (Monica Mutsvangwa) reported that new COVID-19 infections decreased by 49.5 percent with weekly infections decreasing from 21, 346 to 14, 275 (Xinhua, 2021). This showed that the stringent COVID-19 regulations and safety measures worked effectively to contain the virus even though the country remain vulnerable.

Figure 2: Daily new confirmed COVID-19 cases as at March 2020 to July 2021

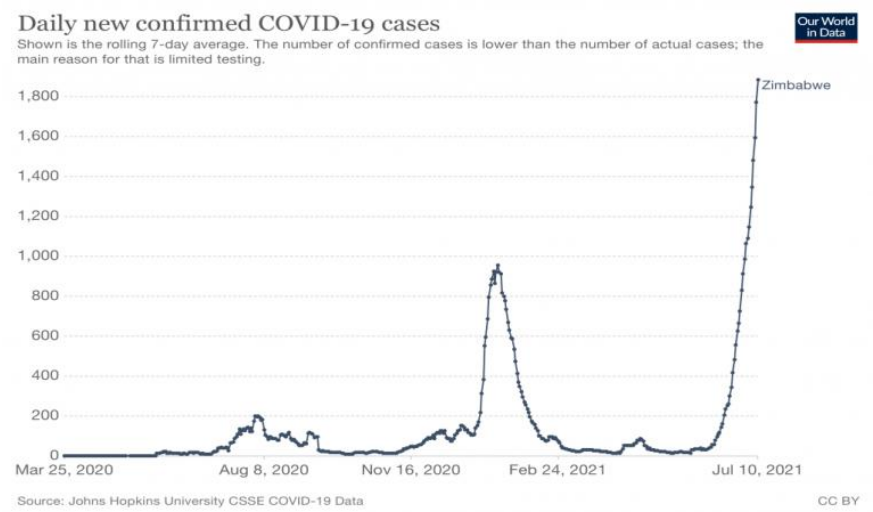

Arguing from a statistical point of view, the data presented in figure above is showing low increase in COVID-19 cases which may mean that the lockdowns worked somehow. One can attribute the declining of virus inflection to level 4 lockdown, public adherence, fear of the pandemic, change of weather or public trust. According to American political scientist Francis Fukuyama, the dividing line in effective crisis response has not been a regime type, "but whether citizens trust their leaders, and whether those leaders preside over a competent and effective state (Lowy Institute, 2021). On the flip side, the peak shown on the figure is showing a silver lining on the ineffectiveness of some COVID-19 preventatives (social distancing, ban on human movement and public gathering, for example) which may however be attributed to relaxation of COVID-19 regulations, cold weather, fatigue, reluctance by people, new infections (e.g., delta variant), super-spreaders, selective application of 
COVID-19 laws, weak enforcement mechanisms, public complacency or denialism. Furthermore, the vaccination of 2976512 people against the virus is an indication that the country is on the right path to attain head immunity. A snap survey done in Harare has shown that most government are no longer workers or visitors who are not fully vaccinated and COVID-19 card are supposed to presented at established security checkpoints. Worryingly, the government has imposed harsh preventative mechanisms without providing adequate social assistance programs (water, food and health services) to meet the needs of its disadvantaged communities for their survival (Zamchiya et al., 2020). As a result, this forced some citizens to risk their lives to the virus in order to survival through vending, hawking, prostitution, thievery, begging and touting thus compromising the efficacy these measures.

\section{COVID-19 Impact on Public Sector Institutions}

Depth analysis of reviewed literature and snap survey has shown that COVID-19 impact to the public sector institutions has led to waning of economic performance, death and illness of critical staffs, contraction of revenue, deferment development projects, restraint of public sector's capability to deliver, disruption of public service delivery and shutting of democratic space.

\section{Waning of economic performance}

COVID-19 pandemic has not spared any aspect of society as it as well caused (still causing) catastrophic implications on the economy internationally, especially countries already experiencing plummeting economic growth. Though the public sector institutions are positioned to drive the economy in any country, this critical role was however crippled by COVID-19 pandemic. This role is provided in Section 13 of the Constitution which states that "the State and all institutions of government at every level must endeavor to facilitate rapid and equitable development" (Constitution of Zimbabwe, 2013). As found by the United Nations Economic for Africa, Africa's GDP growth was predicted to drop from 3.2 percent to 1.8 percent in 2021. As for Zimbabwe, the fragility of its economy can be tracked back 2000 when the government adopted the 'controversial land programme' which some blamed it for wreaking havoc in agriculture sector (Chagonda, 2020). More so, economic sanctions imposed by the west among other factors have also contributed to the drop of the economic performance. According to International Monetary Fund, Zimbabwe's economy contracted by 7.5 percent and inflation rate reached over 500 percent in 2019 which almost returned the country to the era of traumatic hyper-inflation of 2007/8 when the inflation rose to 231 million percent (Chagonda, 2020). The African Development Bank Group (2021) reports that during times of COVID-19 pandemic, the GDP contracted to 10 percent in 2020 with inflation soared, averaging 622.8 percent up from 226 percent in 2019. This was worsened by the advent of COVID-19 pandemic which severely affected the functioning of critical ministries in the country, especially those in the forefront of shaping the economy. In this case, the most devastated ministries include the Ministry of Finance and Economic Development, Ministry of Tourism and Climate Change, Ministry of Lands, Agriculture, Fisheries, Water and Rural Development and Ministry of Foreign Affairs and International Trade, among others. A study conducted Rukasha, Nyagadza, Pashapa \& Muposhi (2021) found that the COVID-19 pandemic has severely threatens an already critical food security situation arising mainly from the prevailing poor macroeconomic conditions and consecutive years of drought in Zimbabwe. The imposition of COVID-19 laws such as closure of borders, ban on human movements and traffic, travel bans and curfews by the government has disrupted trade, tourism, depressed FDI, remittances and stagnated production. On the other hand, market destinations for Zimbabwe's products notably China, Europe and South were severely affected. This in turn disrupted livelihoods expanding the number of extreme poor citizens from 1.3 million to 7.9 million in 2020 (African Development Bank Group, 2020). The prospects of the country to achieve the objectives stipulated in NDS-1 and Vision 2030 will likely to be compromised.

\section{Contraction of critical revenue space}

Available literature on the impact of COVID-19 regulations indicates that this resulted to loss of revenue which further strained pressure on scarce resources (Chilunjika, Chilunjika $\&$ Mutizwa, 2020). For example, the closure of borders, ban on human and traffic movements adversely derailed the Zimbabwe Revenue Authority's (ZIMRA) role to collect revenue in established borders and airports. Other public institutions include Central Registry, Zimbabwe Investment Development Agency (ZIDA), Zimbabwe United Passengers Company (ZUPCO), Zimbabwe National Roads Administration (ZINARA) Airport Company of Zimbabwe, Department of Immigration and local government authorities. As for local authorities, ratepayers were unable to visit council offices to their settle bills because of ban on human movements and stay-at-home orders as the use of e-payment platforms is still limited. The Africa Local Finance Observatory reveals that African local governments, on average, are projected to experience a drop in local finances, in the order of 65 percent under the first stimulation and up to 30 percent under the second (Nyomsi, Yatta, Pozhidaez, Kiwala, Ndugwa, Beguy, Mwaniki, Lalande, Crispi, Kamiya, Gambo, Poournaris, Zulu \& Ghebru, 2020). This means that revenue collection entities are experiencing decline in collection of revenue through tax receipts and service charges which may expose some public sectors to high levels of debts.

\section{Stagnation of development project implementation}

COVID-19, a global pandemic that has become an elephant in the room has severely jeopardised the smooth implementation of government-related development projects across the country. The local government sector that was starting to realise infrastructural improvement through the disbursement of devolution funds were negatively affected due to COVID- 
19 pandemic outbreak acerbated by related restrictions to contain the virus. The Ministry of Finance and Economic Development (MoFED) started to disburse devolution funds in 2019 to kick-start a number of capital development projects at local government level. In the same year, the national treasury released a total of ZWL\$ 657 million to sub-tiers of government against the budgeted ZWL\$ 703 million for devolution programme (Gwata-Charamba, 2020). Harare City Council was among the local authorities that benefited from these funds. In year 2020, national budget sets aside ZWL\$ 2, 93 billion specifically to fund devolution projects though the allocation was gravely derailed by the COVID-19 pandemic. The Sunday Mail News (2020) reports that the national treasury disbursed the funds twice in 2020 to local authorities with the first tranche being a total of ZWL\$310 million and the second batch amounted to ZWL\$ 419 million. In addition to that, the Zimbabwe National Road Administration (ZINARA) under Emergency Road Rehabilitation Programme (ERRP2) is also disbursing funds for road infrastructural development but the pandemic has however affected the progress. This have delayed the government institutions' efforts to accelerate the achievement of the benchmarks set in NDS-1 and Vision 2030 aimed to attain an upper middleincome economy.

\section{Restraint of public sector's capacity to deliver}

As the COVID-19 preventative measures were imposed by the Government in Zimbabwe to contain the continual spread of the lethal virus, the public sector institutions' capacity to delivery was sternly affected. World Bank (2021) reported that the imposition of COVID-19 regulations further disrupted public sector's capacity to provide of basic public services and social protection which were strained pre-COVID-19 era. Those public sector institutions mostly incapacitated include health, education, judiciary and home affairs. This was fueled by lack of human capital, finance capital and limited management operations (Chilunjika, Chilunjika \& Mutizwa, 2020). On lack of human capital side, few selected critical government workers (classified as essential workers) were exempted from reporting for duty during total lockdown period while the rest stayed home. Due to dawn-to-dusk curfew measures, only 10 percent of government workers were allowed to work from office (Kumbuka, 2021). The means that the freedom of movement such as to enter Zimbabwe and move free within the country were comprised in times of COVID-19 lockdowns (Constitution of Zimbabwe, 2013). The essential workers were required to present exemption letters accompanied by work identification at security checkpoints. Those mostly exempted workers include health workers and security officers, among others. Some public institutions were completely closed following workers testing positive. For example, Zvishavane District Hospital closed after twenty five workers were found to be COVID-19 positive (Chilunjika, Chilunjika \& Mutizwa, 2020). As a result, it was estimated that 8.8 percent of working hours was lost in 2020 due to COVID-19 impact (Committee for the Coordination of Statistical Activities (CCSA), 2020). Some workers were forced to work from home through using digital platforms for communication which was not a traditional practice (Daily News, 2020). This however reversed public sector's previously service delivery progress on human socioeconomic development. Though the public sector institutions were severely debilitated to deliver public services, it turned out that the demand of those services (healthcare) increased.

\section{Disruption of public service delivery}

COVID-19 pandemic has not only unprecedentedly interrupted public sector institutions' activities but it further affected its stakeholders. In Zimbabwe, the most hard-hit public sector institution is the formal education which constitute pre-and primary school, secondary school and tertiary colleges. Early global findings as at mid-April 2020 indicates that the pandemic had interrupted formal education of nearly 1.6 billion students in 192 countries (Mutizwa, Buhle, Burt \& Souza, 2020). In Africa, 2.62.5 million preprimary and secondary school children are out of school because of COVID-19-related school closures (Save the Children, 2020). The COVID-19 regulations (ban on human movement and public gatherings, social distancing and closure of schools) made it impossible for education sector, among others, to operate. Some scholars state that COVID-19 has far reaching consequence that would derail the significant gains in education that has been achieved since attainment of political independence in 1980 (Chirisa \& Mundau, 2021). For example, Zimbabwe's literacy rate which one of the highest African has increased from 20 percent in 1980s to 94 percent in 2017 attributed to increase in enrolment in primary school (2 676485 students), secondary school (1 075235 students) and university (100 000) as at 2017 (ZIMSTAT, 2018; $2017 \&$ Tsiko, 2018). This level of literacy can be comprised by the pandemic. Closure of schools has deprived students' right to education as explicitly enshrined in Section 75 of the Zimbabwean Constitution (Constitution of Zimbabwe, 2013). Be that as it may, this article observed that COVID-19 impact on public sector performance is not only affecting Zimbabwe but farther afield. In Britain, a House of Lords Public Service Committee's report acknowledged that public services (health and education) are enormously impacted by pandemic and it may continue for years to come (UK Parliament, 2021). In the vein, the COVID-19 regulations have also further affected the transportation of products from different destinations. Delayed importation of goods such as agricultural and public health products from China and South Africa led to shortages, which thus fueling inflationary pressures (United Nations (UN), 2020). For example, the price survey conducted by Zimbabwe's National Statistical Agency (ZIMSTAT) in April 2020 has shown that health costs rose by 1049 percent (https://www.zimstat.co.zw/). As a result, the right to health care provided in Section 76 of the Constitution is made impossible in situation characterised by COVID-19 pandemic (Constitution of Zimbabwe, 2020). 


\section{Shutting of democratic space}

COVID-19 pandemic and associated regulations have virtually affected every facet of socio-economic functioning, including the democratic space in all levels of governance. The pandemic disrupted the participation of citizens in government programmes that include budgeting, perpetuating inequalities between the elite and the citizens. The adopted COVID-19 regulations such as ban on human movements and public gathering have tremendously interrupted mobilities, forced suspension of public engagement programmes. For example, the pandemic led to the suspension of parliament business and public protests worldwide (Parry, Asenbaum \& Ercan, 2020). Parry, Asenbaum \& Ercan (2020) further argues that the imposition of state of emergency by many countries has served as a justification for authoritarian leaders to further strengthen their grip on power. During the times of national COVID-19 lockdown regimes, the Parliament of Zimbabwe responded by adjourning parliamentary sittings and public consultations on different portfolios. When the lockdowns were relaxed, the parliament adopted virtual and physical parliamentary sittings in order to keep the public institutions operational. At local government level, the local authorities also experienced the shrinking of participatory space were ward participatory budgeting programmes were either shelved or permanently cancelled, undermining the country's constitutional provisision for citizen participation provided in Chapter 14 of the Constitution. According to Mukushwa, Mapuva \& Mutema (2021), this had a net effect on freedoms of assembly, speech and association as the civic space for public participation disappeared. Furthermore, national and elections for people's representatives who were either recalled or deceased were shelved indeterminately due to COVID-19 lockdowns such as limitation on public gathering, ban on human movement, social distancing and stay-at-home orders. This conflict with Section 159 of the Constitution which stipulates that whenever a vacancy occurs in any elective public office, election should be held with ninety day to fill the vacancy (Constitution of Zimbabwe, 2020). One ponders whether the Constitution still have a foothold to maintain the status of being the 'supreme law of the land' as it failed the litmus test of COVID-19 lockdowns.

\section{Death or illness of critical expertise}

The outbreak of COVID-19 pandemic has not only sternly decapitated public sector institutions but has further caused sudden deaths and illness to executive and non-executive government workers. As at 10 August 2020, about 10 percent of the confirmed COVID-19 cases in Zimbabwe were publicfrontline health care workers (nurses, student nurses, doctors, laboratory scientists, general hands and pharmacists) which translate to 480 (Xinhua, 2020). By late February 2021, about 4000 health workers had tested positive and 18 deaths. Some health workers succumbed to the virus. The Secretary General for Zimbabwe Association of Doctors for Human Rights stated the morale to report for duty was just low mainly because of poor working conditions and low remunerations
(Masiyiwa, 2021). Yet, every person has a right fair and safe labour practices and standards and to be paid a fair and reasonable wage that is according to the Constitution of Zimbabwe in Section 65 (1) (Constitution of Zimbabwe, 2013). This prompted the public health workers to strike against limited COVID-19 testing, poor working conditions, indecent salary, lack of protective clothes (Personal Protective Equipment) and closure of health facilities. These unbearable working conditions are fueling brain drain in the health sector as they search greener pastures to developed countries such as Britain, Island and Australia. The Chairman of Zimbabwe Nurses Association (Enock Dongo) warned that health care workers are increasingly the country which continue to dwindle thus comprising the quality of health care in the country (Masiyiwa, 2021). In 2020, more than 1000 health care workers resigned. Professor Auxilia Chideme Munodawafa, a Chairperson of Health Service Board of Zimbabwe revealed that Zimbabwe has 44, 067 health care workers, which is less 4, 580 less than the country requires. Furthermore, the government also lost government ministers and senior administrators that were critical in transforming Zimbabwe's national economy.

Unearthing COVID-19 Pandemic's new opportunities to the public sector

Even though the onset of COVID-19 pandemic and government regulations have drastically affected the public sector devastatingly, the pandemic on the other hand have unearthed potential opportunities that are critical for public sector modernisation in Zimbabwe and far afield. The COVID-19 pandemic has opened a critical opportunity for the country to consider the importance of embracing new digital innovations in improving its public governance practices. In addition to this, the COVID-19 pandemic has unearthed an opportunity for the government to increase internet connectivity countrywide in order to close the digital divide in the education sector, for example. COVID-19 pandemic also helped the government to recognise the importance of the health care institutions in fighting COVID-19 pandemic and future pandemics. The pandemic has presented the opportunity for the government to consider having vibrant and self-sufficient public sector institutions, which do not largely rely on donors particularly the health care sector. Also, the COVID-19 pandemic has presented an opportunity for government to strengthen social welfare programmes that target the marginalised communities by availing enough funds unlike the present situation. Further than this, the government should use the COVID-19 pandemic as an opportunity to ensure economic stability and formulate policies or programmes that benefit the governed community.

\section{CONCLUSION AND RECOMMENDATIONS}

The article has assessed the impact of COVID-19 pandemic and government imposed-regulations to the public sector practices in Zimbabwe, cross-sectionally. The article further evaluated the efficacy of COVID-19 preventative measures in suppressing the virus. A number of conclusions has been 
made by this paper. First, it is crystal clear that COVID-19 pandemic and associated regulations have negatively impacted on the functioning of public sector institutions to the extent that some sectors were completely shut down particularly the education sector. Second, the onset of COVID-19 pandemic has presented new opportunities for the public sector to rethink its administration practices. The paper found that the COVID-19 regulation and safety measures adopted by the Government of Zimbabwe has performed fairly to contain the spread of the virus. This is supported by decrease in deaths and infection cases as well as increase in recoveries. Among other issues, the devastating impact of COVID-19 pandemic to the public sector institutions has led to death and illness of critical staffs, contraction of revenue, stagnation of development project implementation, restraint of public sector's capability to deliver, disruption of public service delivery and shutting of democratic space. It also emerged that the most hard-hit public sectors include health care and education institutions which require a paradigmatic shift in the way of delivering public services. In addition to this, the findings on the other hand have indicated that the advent of COVID-19 pandemic has unearthed new opportunities for accelerating the adoption of e-governance strategies in order to be resilient against the virus and COVID-19 lockdowns.

Furthermore, prolonged COVID-19 pandemic and stricter regulations has accelerated the need to embrace the use of Information Communication Technologies (ICTs) in the public sector in order to stay afloat and be relevant to the society it serves. New Digital Governance is the way to go, so as to complement traditional practices now and aftermath of COVID-19 era. Though it is a noble idea to accelerate the use digital platforms in public sector in times of COVID-19 and in future, there is need for the government (and private sector) to increase domestic internet connectivity, minimise erratic supply of electricity, reduce cost of bundles, adopt cloud and artificial intelligence, introduce enabling laws and policies, increase infrastructure support and increase mobile network. More pointedly, the public sector should put in place counter mechanisms to deal with remote working risks such as hacking, cyber security, indiscipline and failure of digital infrastructure. At the time of writing, it seemed the government was still lagging behind in terms of digitalising the public sector to ameliorate service delivery, which is widening digital divide.

\section{ACKNOWLEDGEMENTS}

The authors did not receive any form of assistance for this work.

\section{REFERENCES}

[1] African Development Bank Group. (2020). Zimbabwe Economic Outlook. Retrieved from: www.afdb.com.

[2] Alinska, A., Filipiack, B.Z \& Kosztowniak, A. (2018). The Importance of the Public Sector in Sustainable Development in Poland. Journal of Sustainability. 1-24. Retrieved from: www.mdpi.com/journal/sustainability.
[3] Betchoo, N.K. (2016). Public Sector Management: A Millennium Insight ( $1^{\text {st }}$ ed). Cyrus Jones, Graduate Hopkins University: USA. 6-122.

[4] Botchwey, K., P., Collier, J., W; Gunning and Hamada, K. (1998). Report of the Group of Independent Persons appointed to Conduct an Evaluation of Certain Aspects of the Enhanced Structural Adjustment Facility, Washington DC, IMF.

[5] Bowen, G. (2009). Document Analysis as Qualitative Research Method. Qualitative Research Journal. 9 (2), 27-40. Doi 10.3316/6/QR0902027.

[6] Chagonda, (2020, 12 April). Zimbabwe's Shattered Economy poses a serious challenge to fighting COVID-19. The Conversation. Retrieved from: www.theconversation.com.

[7] Chirisa, I \& Mundau, L. (2020). The Impact and Implications of COVID-19: Reflections on Zimbabwean society. Social Sciences and Humanities Open. 4 (1). Retrieved from: https://doi.org/10.1016/j.ssaho.2021.10083.

[8] Committee for the Coordination of Statistical Activities. (2020). How COVID-19 is Changing the World: A Statistical Perspective. Retrieved from: https://nd/.handle.net/10986/33773.

[9] Constitution of Zimbabwe (No.20). Act 2013.

[10] Cordin, J \& Strauss, A. (2006). Basic of Qualitative Research: Techniques and Procedures for Developing Grounded Theory. Thousand Oaks, CA: Sage.

[11] Curristine, T., Lonti, Z \& Joumard, I. (2007). Improving Public Sector Efficiency: Challenges and Opportunities. OCED Journal on Budgeting. 7 (1), 1-42.

[12] Government Actuary's Department. (2020). The Impact of COVID-19 on Public Sector Insurance: Survey Results. 3-10.

[13] Hindson, J. (2020). COVID-19; faecal-oral transmission? Nat. Rev. Gastroenterol. Hepatol. 17. Retrieved from: http://doi.org/10.1038/s41575-020.0295-7.

[14] Hood, C. (1991). "A Public Management of all seasons". Public Administration. 69 (1), 3-19.

[15] Jan-Erik, L. (2000). The Public Sector: Concepts, Models and Approaches. $\left(3^{\text {rd }}\right.$ ed). Sage Publications.

[16] Kumbuka, D. (2021, 22 January). Only $10 \%$ Zimbabwe government staff working in offices amid COVID-19 surge. BusinessDay. Retrieved from: www.businessday.co.za.

[17] Larbi, G. A. (1998). The New Public Management Approach and Crisis States. UNRISD. Geneva.

[18] Li, G. (2021). Nikkei COVID-19 Recovery Index. Retrieved from: www.asia.nikkei.com.

[19] Lowy Institute. (2021). COVID-19 Performance Index: Decongesting Pandemic Response. Retrieved from: www.interactive.lowyinstitute.org.

[20] Masiyiwa, G. (2021). Scarred by COVID Battle, Health Workers Lack Support. Global Press Journal. Retrieved from: https://globalpressjournal.com.

[21] Mazzussato, M \& Kattel, R. (2020). COVID-19 and Public Sector Capacity. IPP. Working Paper. UCL Institute for Innovation and Public Purpose. 1-19. Retrieved from: https//www.ucl.ac.uk/Bartlett/public/wp2020-12.

[22] Molens, D. M., Taubenberger, J. K and Fauci, A. S. (2009). The Persistent legacy of the 1918 influenza virus. N. Engl. J. Med. 361, 225-229.

[23] Ministry of Health and Child Care. (2021). COVID-19 Updates. Retrieved from: www.mohcc.gov.zw.

[24] Mukushwa, Z. C., Mapuva, J and Mutema, E. P. (2021). The Practice of Participatory Budgeting during the COVID-19 Pandemic in Zimbabwe's Local Government Sector: A Case of Chitungwiza Municipality. The African Review. 24, 1-24. doi: 10.1163/1821889X-12340057.

[25] Mutizwa, M., Buhle, F., Burt, J \& Souza, B. (2020). Education in times of COVID-19: Looking for Silver Linings in Southern Africa. Education Responses. Southern African Journal of Environment Education. 36, 1-16. doi.10.4314/sajeez.36.17.

[26] Nyomsi, C., Yatta., F Pozhidaez, D., Kiwala, L., Ndugwa, R., Beguy, D., Mwaniki, D., Lalande, C., Crispi, G., Kamiya, M., Gambo, M., Poournaris, M., Zulu, J \& Ghebru, Y. (2020). 
COVID-19 in African Cities: Impacts, Responses and Policies. UN-HABITAT, UNCDF, UCLG-Africa and UNECA. 4-29.

[27] Palrao, T., Rodrigues, R.T \& Estervao, J.V. (2021). The Role of the Public Sector in the Aftermath of COVID-19 Pandemic crisis: The Case Portuguese events' industry. Journal of Convention and Event Tourism. Doi.1080/15470148.2021.1904077.

[28] Parry, L. J., Asenbaum, H and Ecran, S. A. (2020). Democracy in Flux: A Systematic view on the Impact of COVID-19. Emerald Publishing Limited. 1-9. Retrieved from: https://www.emerald.com/insight/1750-6166.htm.

[29] Popa, F. (2017). Public Sector: Concepts, Elements, Implications in Economic and Social Life Studies and Scientific Researches, Economies Edition. 25, 49-56.

[30] Save the Children. (2020). Save the Children: Outbreak could cause millions of children to suffer for years to come. Retrieved from: $\quad$ https://www.savethechildren.org/us/about/media-ednews/2020-press-releases/outbreak-could-cause-years-tochildrensufferingforchildren.

[31] Stephens, Z. (2021). List of Countries without Coronavirus. Retrieved from: www.korgogroup.com.

[32] Therkilden, O. (2001). Efficiency, Accountability and Implementation: Public Sector Reform in East and Southern Africa. Democracy, Governance and Human Rights Programme Paper Number 3. United Nations Research Institute for Social Development. 1-54.

[33] Gwata-Charamba, R. G. (2020, 6 March). Zimbabwe: Setting Up the Public Sector for Improved performance. The Herald News. Retrieved from: www.africa.com.

[34] The Institute of Internal Auditors. (2011). Supplementary Guidance: Public Sector Definition. Global. 3-6.

[35] Tsiko, S. (2018). Fall Armyworm infests 150 000ha of Zimbabwe maize. The Herald News. Retrieved from: https://www.herald.co.zw.

[36] Umakanthan, S., Sahu, P., Ranade, A. V., Bukelo, M. M., Rao, J. S., Abrahao-Machado, L. F., Dahal, S., Kumar, H and Dhananjaya, K. V. (2020). Origin. Transmission, diagnosis and management of coronavirus disease 19 (COVID-19). Postgrad Med J. 96, 753-758.

[37] UK Parliament. (2021). Public Service: Impact of the COVID-19 pandemic. Lords Library. Parliament UK. Retrieved from. www.lordslibrary.parliament.uk.

[38] United Nations. (2020). Immediate Socio-Economic Response to COVID-19 in Zimbabwe: A Framework for Intergrated Policy Analysis and Support. United Nations of Zimbabwe.

[39] Xinhua. (2020, 11 August). Medical workers make up to 10 percent of Zimbabwe's confirmed cases. Xinhuanet News. Retrieved from: www.xihuanet.com.

[40] Xinhua. (2021). Zimbabwe maintains strickest lockdown despite decrease in COVID-19 Inflections. Xinhuanet News. Retrieved from: www.xinhua.com.

[41] Xu, J., Zhao, S., Teng, T et al. (2020). Systematic comparison of two animal-to-human transmitted human coronaviruses: SARSCoV-2 and SARS-CoV-2. Viruses. 12. E244.

[42] World Bank. (2020). Zimbabwe: COVID-19 further complicates Zimbabwe's and social conditions. Retrieved from: www.worldbank.org.

[43] World Health Organisation. (2020). WHO announces COVID-19 outbreak a pandemic. Retrieved from: http://www.euro.who.int/en/health-topics/healthemergences/coronavirus-covid-19/news/news/2020/whoannounces-covid-19-outbreak-a-pandemic.

[44] WHO. (2021). WHO Coronavirus (WHO) Dashboard. www.zimstat.co.zW 